\title{
A possible solution for corruption in South Africa with the church as initiator: A practical theological approach
}

\author{
Authors: \\ Amanda L. du Plessis ${ }^{1}$ \\ Gert Breed ${ }^{1}$ \\ Affiliations: \\ ${ }^{1}$ Department of Practical \\ Theology, North-West \\ University, Potchefstroom \\ Campus, South Africa \\ Note: \\ This article was originally a \\ paper delivered at the Joint \\ Conference of Academic \\ Societies in the Field of \\ Religion and Theology, held \\ at the University of KwaZulu- \\ Natal, Pietermaritzburg \\ Campus, South Africa, from \\ 18 June to 22 June 2012 \\ This article is published in the \\ section Practical Theology \\ of the Society for Practical \\ Theology in South Africa. \\ Correspondence to: \\ Amanda du Plessis \\ Email: \\ amanda.duplessis@nwu.ac.za \\ Postal address: \\ Private Bag X6001, \\ Potchefstroom 2520, \\ South Africa \\ Dates: \\ Received: 05 July 2012 \\ Accepted: 17 Sept. 2012 \\ Published: 20 Mar. 2013 \\ How to cite this article: \\ Du Plessis, A.L. \& Breed, G., \\ 2013, 'A possible solution for \\ corruption in South Africa \\ with the church as initiator: \\ A practical theological \\ approach', HTS Teologiese \\ Studies/Theological Studies \\ 69(2), Art. \#1298, 10 pages. \\ http://dx.doi.org/10.4102/ \\ hts.v69i2.1298

\section{Copyright:} \\ (C) 2013. The Authors. \\ Licensee: AOSIS \\ OpenJournals. This work \\ is licensed under the \\ Creative Commons \\ Attribution License. \\ Read online:

According to Transparency International, Africa is the most corrupt region in the world. In South Africa, there is an annual 'loss' of about R30 billion as a result of bribery and corruption. It would appear that it is exactly the poor and the vulnerable who suffer most under the scourge of corruption. The purpose of this research was to investigate the effect of corruption on victim(s) and to evaluate it in an effort to formulate solutions as to how such individuals can be guided and supported in the suffering and hardship that they endure and that specifically emanate from corruption. In the research, an effort was made to move away from the trend of the fragmenting of aid and to present guidelines or suggestions that can lead to a global solution, where multi-disciplinary involvement can be facilitated. The researchers agree that the church can play a key role in this, and the solution was sought in the principles expounded in 1 Corinthians 12. The research method known as action research was investigated as a workable method to be used by the multi-disciplinary aid team in their struggle against corruption. In the final instance, the principles used by Touching Africa in their work were investigated so that these could also be used in the quest for a solution.

\section{Introduction}

According to Transparency International, the highly respected counter-corruption organisation situated in Berlin, Africa is the most corrupt region in the world. Mr Willie Hofmeyr, former head of the Special Investigative Unit (SIU) recently alleged that bribery and corruption cost South Africa in the vicinity of R30 billion per annum (Worrall 2011:3). This is an enormous amount of money that under normal circumstances could have been used to create jobs and develop infrastructure. According to Vorster (2012) corruption can be defined as follows: 'Corruption is the misuse of public office or a position of authority for private material or social gain at the expense of other people.' It would therefore appear that it is precisely the poor and the vulnerable who suffer most under corruption. In this research, it is the objective of the authors, in the first place, to observe contemporary praxis from which, in the second place, possible perspectives can be derived for the accompaniment and support of people who are affected in one way or another through the devastating impact of corruption.

The methodology adopted for this research was directed at pinpointing the problem in practice and to propose strategies aimed at solving the problem. A qualitative approach was followed that constructs cultural meaning and that focuses on interactive events where fidelity is the key factor. The researchers did field surveys with the primary aim of obtaining factual information with regard to reality for the purposes of description, explanation or planning. During the field surveys, the researchers did only observation, and the data-collection was done by way of unstructured interviews. The purpose of the interviews was not to find answers to questions or to test hypotheses, but to try to understand the experiences of the participants and to observe their responses to those experiences and reaction towards aid given (Strydom 1999:72-84). In this research, an attempt was also made to establish guidelines that could help develop resilience to assist in absorbing the impact of corruption on society or at least to try and decrease it. An effort was also made to move away from the trend towards fragmentation of aid and to establish guidelines that can help effect a global solution where multi-disciplinary involvement can be facilitated. The researchers agree that the church can play a key role in this regard, and for the present, the solution is sought in a tentative model in which the principles expounded in 1 Corinthians 12 for ministry in churches are given and aligned with different bodies working towards addressing the problems associated with corruption. The intention is therefore to make proposals for a pro-active model that can offer a solution to the victims because the researchers have come to the conclusion that the solution to the problem of corruption and its invidious effects lies in the joining of forces. This conviction will serve as the point of departure for the research. The four tasks that Osmer (2008) regards as the research tasks of practical theology can also be postulated, from the point of view of previous research, as the tasks of the church in the limiting of corruption in South Africa:

- The church should, with priestly listening, note the suffering emanating from corruption. This is done in the first part of this article. 
- The church has to apply sagely wisdom to discover the root cause as to why corruption flourishes practically unchecked in our society, viz. the lack of unity and cooperation amongst the different parties who have the gifts to do something about the matter. The second and the third parts of the article represent an attempt at this.

- The church has to co-operate with prophetic discernment towards the finding of solutions for the broken society that we have as a result of the violence of corruption. This is addressed in the fourth section of this article.

- The church has to take forward the notion of diakonia or servant leadership of Christ in this world. Christ's diakonia came to fruition with his death on the cross and the sending of his Spirit to us as consolation and to lead us in the fullness of truth. The Spirit-filled Church will minister the manifold grace of God in a broken world even if the ultimate sacrifice is required, and it will so become true consolers of those in pain through servant leadership. This is the calling of the church for the near future as identified in the article.

\section{Alleged corruption in the Aurora mining group}

For the purposes of this article, attention is directed at the effect that alleged corruption had on the employees at the Aurora Group of Mines. A cross-section of the problem is represented in the study in order to illustrate something of the impact of corruption on society. The first step of Osmer's practical theology model is the focus of the first part of the study, and his empirical approach allows the researchers to listen with priestly understanding to suffering associated with corruption as well as to the consequences of aid given. The researchers became deeply aware of the total sense of helplessness experienced not only by the victims but also by the aid-givers. This feeling can be attributed to the enormous scope of the problem, and for that reason, a onesided approach to the provision of aid is inadequate. In the description of the problem, background details are provided, and subsequently, reports are supplied about the different interviews with employees and an aid-giver, and finally, the relevant data are analysed. All the recipients who took part in this study gave their permission for the information to be used. The names of the recipients are their real names and the signed permissions are in the possession of the researchers.

\section{Background information}

In an interview ${ }^{1}$ that the researchers conducted with $\mathrm{Mr}$ Gideon du Plessis, Deputy Executive Head of Solidarity, the following background details were obtained. In April 2009, Pamodzi Gold was placed under provisional liquidation by the North-Gauteng High Court. At the time of the liquidation, Pamodzi was the owner of the President Steyn Mine in Welkom, the Orkney Mine in the Orkney region and the Grootvlei Mine on the East Rand. Harmony Gold bought the President Steyn Mine out of liquidation, and a Black empowerment company, Aurora Empowerment Systems 1.The interview took place on 15 March 2012 in Potchefstroom.
('Aurora'), made an offer of R605 million for the Orkney and Grootvlei Mines in October 2009. In their offer to purchase, Aurora made various promises about building clinics, rehabilitating the mining environment and funding study bursaries for the children of employees. Aurora also made it clear in their offer that they had already obtained funding and that they were fully capitalised for purposes of further developing the mining assets and infrastructure. On 13 October 2009, the Pamodzi liquidators appointed Aurora as the buyer of choice to manage the two mining assets on their behalf and gave them three months to transfer the necessary funds. According to Du Plessis, the transfer was never made, and following information provided to unions and various state institutions by Aurora staff, it became known in April 2010 that, although gold production continued, virtually no creditors were paid. The estimated amount owed to suppliers is in excess of $\mathrm{R} 100 \mathrm{~m}$. Since the mining production came to a halt in March 2010, Aurora plundered and sold mine assets. During a recent insolvency inquiry, it came to light that the replacement damage caused to the mines during the period April 2010 - April 2011 amounts to approximately R1.7bn. Aurora was finally removed from the mines after a long legal battle and liquidated in October 2011, following liquidation applications by various service providers lodged against them. A salary claim to the amount of $\mathrm{R} 4.7 \mathrm{~m}$ was filed by Solidarity.

At the time of the appointment, both mines were fully operational with an experienced workforce of 5300 employees. However, in January 2010, the salaries of staff were at first paid late and then paid only partially. As a result of promises of payment of outstanding salaries, the staff went on with production, but in February 2010, no salaries were paid, and the outstanding salaries were not paid either. When payment of salaries still did not realise by 15 March 2010, the underground workers went on strike. On 18 March 2010, 4800 employees were 'temporarily' retrenched, and only 500 employees were kept on the payroll for purposes of essential maintenance. Various statutory deductions were made on the pay of employees, such as pension-fund contributions, unemployment insurance and employee tax, but none of these were paid over to the relevant bodies because Aurora was not registered with any of the statutorily compulsory bodies.

The most devastating impact of the Aurora legacy on employees, however, was the non-payment of salaries that impacted hugely on the employees. A large number of the employees and their dependants were dumped into abject poverty because of this gross mismanagement. The City Press (Pauw 2012:3) alleges that about 42000 people's lives were affected directly or indirectly by this. One person, Marius Ferreira, paid the highest price by committing suicide. Various marriages and families broke up. At present, there are still employees who live in mine hostels because they have no other recourse. Many of them come from the neighbouring states, and their work permits and passports have expired in the meantime. 


\section{Interviews during the field surveys}

Because of the sampling, it was decided to have interviews with (1) Ms Susan Ferreira, widow of Marius Ferreira, (2) Messrs Elias van Rensburg and M.P. Pelembe, inhabitants and representatives of the 150 employees still living in the hostel of the Pamodzi Five Shaft and (3) Mr Kobus Jansen van Rensburg, a former employee of the Grootvlei Mine, who was doing reasonably well, in spite of what he and his family had gone through. The choice of interviewees was done on the basis of (1) the highest price paid, (2) people who were still on a daily basis exposed to the effect of the corruption and (3) a success story that played itself out in spite of the corruption.

The purpose of the interviews was to try and understand the experiences of the relevant individuals and to observe their responses to these experiences. All the relevant people gave their permission to be interviewed and for the information to be used. A further interview was also done with the Rev. Rika van Staden, Reformed (Hervormde Kerk) minister in Welkom. She had been very involved in the organization of the aid programme.

\section{Interview with Ms Susan Ferreira ${ }^{2}$}

The interview with Ms Ferreira took place telephonically on 12 April 2012 at $11 \mathrm{~h} 00$. At the time of the interview, her husband had already been dead for a year. She was very emotional and cried whilst telling her story. Following the death of her husband, she was forced to move to a flat in a retirement facility. She told of how, even during the period of not being paid, her husband had remained positive that everything would work out and that, motivated by hope for a positive outcome, he had remained part of the maintenance team. Financially, however, things went downhill, and they were forced to sell their vehicle, furniture and even some of their curtains simply to live. She told of how her husband had felt totally helpless and worthless, that he felt as if he had been robbed of his human dignity because he was not able to provide and to care any longer. His emotional deterioration was a gradual process as their physical resources were exhausted. In March 2011, he took ant poison and died four days later. Before dying, he apologised to his wife for what he had done and for the fact that she would have to go on by herself.

From my conversation with Susan, I could deduce that it was very difficult for her to accept the circumstances. She experienced intense grief and even shock that their once seemingly happy lives could change so radically because of circumstances beyond their control. Financially it is still very difficult, and she is dependent on an old-age pension and the hand-outs of others. During the discussion, she kept on repeating the words: 'Dit is baie baie swaar' ['it is very hard']. I could make the deduction that Ms Ferreira was not well spiritually, physically and socially, and that she still, on a daily basis, suffers as a result of the events. She is not receiving any psychological or pastoral help to assist her with coming to terms with the situation. A reasonable assumption can therefore be made that the aid given to this family was inadequate.

\section{Interview with Messrs Elias van Rensburg and M.P. Pelembe ${ }^{3}$}

The interview took place on 12 April 2012 at $14 \mathrm{~h} 00$ at the hostel of the Pamodzi Mine, Five Shaft, Orkney. Messrs Van Rensburg and Pelembe live in the hostel and act as representatives for the about 150 employees living in the hostel with their families. Apart from the good infrastructure of the buildings, the deterioration is very evident. For almost a year, no electricity has been provided. The majority of employees are living in abject poverty and have no other recourse. The atmosphere on the site was one of quiet restfulness, and little groups of people sat and talked around the area. According to Mr Van Rensburg, the conversations largely deal with the situation on the mine and the uncertainty surrounding the future. On weekdays, the organization Gift of the givers provides the inhabitants with a meal, but on weekends, they have to fend for themselves. On Sundays, various ministers from the surrounding areas hold services in the church building on the site. Not everybody attends the services, but those who do attend regard this as a weekly high point where they gain strength. I could make the deduction that, in spite of the fact that some have managed to accept their lot and to wait patiently until total production could be resumed, the overall feeling is one of total helplessness and a lack of hope. The uncertainty about the future is tangible, as well as disbelief that their once good existence could so fully disappear. Although Mr Pelembe (himself a tent-maker pastor) is worried about the lot of the other employees, his own emotional situation is good. He enjoys the support of an extended family. Mr Van Rensburg, however, confessed that he experiences many mood swings, and that at times, he had entertained visions of suicide as an escape.

From my interview with Messrs van Rensburg and Pelembe, I could deduce that the support is very fragmented and therefore limits the possibility to address the needs of those involved in full. Messrs Van Rensburg and Pelembe are supposed to represent the approximate 150 employees, but it appears that none of them take the responsibility - or have the resources - to initiate or facilitate the support offered by organisations, church organisations, individuals, et cetera. This result in sporadic contributions without proper evaluation of the need, and it contributes to the escalation of the crisis.

\section{Interview with Mr Kobus Jansen van Rensburg ${ }^{4}$}

The interview took place telephonically on 11 April 2012 at $14 \mathrm{~h} 00$. Mr Kobus van Rensburg was very helpful and willing to enter into conversation with me about the effect that the corruption has had on his family. He was part of the maintenance team that stayed on after the other employees had had to leave the mine. He left the Grootvlei Mine in

3.Messrs Elias van Rensburg and M.P. Pelembe are former employees at the Pamodz Mine in Orkney.

4.Mr Kobus Jansen van Rensburg is a former employee of the Grootvlei Mine in Springs. 
January 2011 after a period of service of 10 years and 11 months because he had been able to find a new job at a mine in Swartruggens. He told of how they had suffered a lot of financial hardship - to the extent that he became involved in a court case because he could not pay his rent. He acknowledges that the day of the court case had been the absolute end for him as it felt as if he had been stripped of all his dignity because he could not care for his family. The idea of a family murder even began to invade his thoughts. A reporter from a local radio station heard of them and came to do an interview with him. The response from the public was overwhelming, and they were able to pay their debts. After this, he received the job in Swartruggens, and they moved. One of his daughters, however, requires special schooling and is now living with her grandparents in Tzaneen because Swartruggens has no school offering that kind of education. The family experiences this separation as traumatic, but apart from that, they are well. Kobus says that the whole experience has led to an intensification of their relationship with God and also with each other. He experiences this as a second chance given to them, and they live it fully.

After my interview with Mr Jansen van Rensburg, I could conclude that, during the process of aid to this family, the situation was by no means fully addressed. The question is: What would have happened if the reporter did not almost accidently come to hear about their needs and unbearable situation. Or what could have happened if Mr Jansen van Rensburg did not receive the new job? Although Solidarity visited the family from time to time, and the close family provided food parcels, they were left to their own devices. Also, no psychological or pastoral assistance was offered to defuse the mental and emotional impact on them.

\section{Interview with the Rev. Rika van Staden}

In the conversation that the researchers had with Mr Gideon du Plessis of Solidarity, he indicated that he had realised very early in the process that the aid provided was inadequate and that the support was fragmented. Solidarity became involved largely in the provision of physical aid, but in spite of that, they discovered that people were becoming more and more demotivated, and it became clear that other disciplines had to be drawn into the aid process. Consequently, they approached the Rev. Rika van Staden, Minister in the Reformed Congregation (Hervormde Gemeente) in Welkom to learn more about the way her team helps employees at the President Steyn Mine in Welkom. In an email (Van Staden, R., 2012, email, 28 March) to the researchers, she explained the procedure followed. Initially, the problem appeared to be totally overwhelming, but through the involvement of various role-players, they could lessen the impact of the corruption. The provision of aid came from various disciplines, viz. ministers, businessmen, the local radio station, a dietician, a trauma-counselling group and prayer-group co-ordinators. She sums up the experience as follows:

This was a project where my heart got to know the people of Welkom. It was a project where I saw how a whole community learnt how not to try to be in control of everything by themselves - it was simply impossible. I had to trust in the Lord to send others with gifts that He had given, to help in their specific area. I had to learn how to take hands. With our hands together we could bear so much hurt. Alone, we would have fallen. ${ }^{5}$

From the foregoing empirical research, the following important guidelines can be made in the quest for a more profound solution for support given to those affected by corruption in South Africa:

- The researchers could conclude that, when aid is not initiated and facilitated by responsible and equipped persons, it remains fragmented and therefore inadequate to address the situation in full.

- The church has a particular role to play in society by engaging actively in helping people who suffer from the effects of disasters such as corruption. In this regard, the Rev. Van Staden, from the town of Welkom, proved what the positive impact of aid can be when properly initiated and facilitated.

- The impact of corruption on society is immense, and aid workers may experience it as overwhelming. Therefore, the role of the church is all the more necessary because of the wisdom and guidance that can come from God, through prayer. The believers thus know and stand assured that God will guide and lead them in the process.

- In addition, other institutions and individuals, who have a positive contribution to make, may also be involved. However, it is essential that the process be well coordinated in order to avoid duplication and/or neglect of certain needs.

- Assistance cannot be provided unilaterally because the enormous impact of corruption on society is so great that only a multi-dimensional application, such as the church, with well-coordinated efforts can address such situations.

Retief (2010), in her book Genesing vir trauma in die Suid Afrikaanse konteks [Healing trauma in the South African context] defines trauma as follows:

A person has experienced trauma if he/she has been exposed to events that have to do either with life experiences, or with a phase of life (for example, moving on from one phase of life to another or circumstances emanating from a transition from one phase to another that the person finds unmanageable) and which has the result that that person's ordinary managing mechanisms have been paralysed and at least one of the following effects can be observed: (1) an element of resignation is present; (2) there is a deep, almost irreversible change in a basic view of life or conviction; (3) there is a serious over-burdening of people normal management mechanisms. ${ }^{6}$ (p. 17)

The above definition sums up very clearly the conclusions drawn during the field surveys. During the interviews, I

5.'Hierdie was' $n$ projek wat my die hart van Welkom leer ken het. Dit was ' $n$ projek waar ek gesien het hoe' $n$ hele gemeenskap geraak is hierdeur. Dit is 'n projek waar ek geleer het om nie self alleen in beheer van alles te wou wees nie - dit was bloot onmoontlik. Ek moes die Here vertrou om ander te stuur met gawes wat Hy gegee het, om te help op hul spesifieke terrein. Ek moes leer hande vat. Met hande, saam, kan ons soveel seer dra. Alleen sou elkeen van ons geval het.'

6." $n$ Persoon het ' $n$ trauma beleef indien hy of sy blootgestel was aan gebeure wat te make het óf met sy of haar lewensomstandighede, óf met sy of haar lewensfase (byvorbeld die ory (byvoorbeeld die oorgaan van van ' $n$ nuwe lewensfase wat die persoon onhanteerbaar vind) en wat tot die gevolg het dat daardie persoon se gewone hanteringsmeganismes lamgelê is en ten minste is teenwoordig; (2) daar is ' $n$ diep, amper onomkeerbare verandering in ' $n$ basiese lewenssiening of oortuiging, en (3) daar is ' $n$ ernstige oorbelading van die mense se normale hanteringsmeganismes.' 
came to a very clear awareness of how enormous the impact of the corruption had been on these people's lives - and still is. According to Retief (2010:13), the Greek word for trauma means wound. The concept of suffering is problematic (Hall, Langer \& McMartin 2010:111) and causes challenges to theology, psychology and philosophy. The theologian is challenged about the theodicy issue, the psychologist about the impact of trauma on man's human dignity and the philosopher has to reflect on the meaning of life anew. A contributing factor to the impact of the events on lives of the victims was the utter unexpectedness of it all. The knowledge that they could do nothing about their situation left some with a sense of hopelessness and terror with tragic results. The opposite was also true, however. Some could, in spite of the hardship and suffering, grow because certain other resources, such as a new job or the support of an extended family, were in place. These were the ones who could testify that they had experienced greater profundity in their relationships and also that a change had occurred in the way in which they looked at life. For example, they had developed greater resilience, wisdom and inner strength together with a keen sense of vulnerability and the limitations of self. The truth, however, is that the South African society today cannot turn away from people like these and leave them to their own devices. Certain steps will have to be put into place to care at all levels of the life experiences of the growing number of victims of corruption.

\section{Quest for a solution}

The above situation is only one example of what the effect of corruption on people can be. It does not begin to describe the effect of corruption on the economy of the country and the social situation as a whole, even in our neighbouring countries. It is clearly the task of researchers to reflect on this situation. Material and pastoral care of the individual or family affected by corruption is certainly part of the answer to the problem as described above. What has also emerged from the research as outlined above is the helplessness of the church and other aid agencies to prevent the suffering emanating from such corruption. The various role players could, in the case of the Aurora and Pamodzi Mines, alleviate the suffering only to some extent. This article will therefore seek to find a more profound solution. In an effort to achieve this, the principles expounded in 1 Corinthians 12 will be studied to derive from there guidelines for the action of the church. Then the relevance of action-oriented research (action-driven research) for this approach will be investigated. The working model of Touching Africa is explored to provide further guidelines. Finally, a working plan is suggested to address the problem of corruption.

\section{The task of the church with a view to the eradication of corruption}

In this section, there is a focus, derived from a study of 1 Corinthians 12, on the task of the church with regard to corruption. The assumption of the researchers is that the Bible determines not only what the church must do but also what the church must be in this world. In practical theology, the researcher must establish the guidelines out of Scripture and apply them to the practical situation that is researched. According to the model of Osmer, the question, 'What ought to be going on?', will be answered in this part of the article. The grammatical-historical method of exegesis is followed.

In the first Epistle to the Corinthians, the relationship of the congregation vis-à-vis the world is touched on throughout. In the first three chapters, the wisdom of God (which in the eyes of the world is foolishness) to which the congregation has access is mentioned time and again and contrasted with the wisdom of the world (cf. 1 Cor 1:20, 21, 27, 28; 2:6, 8, 12; $3: 18,19$; Bruce, 2000:418). In 1 Corinthians 2:15, it is said of the pneumatikos, the person who has the Spirit of God, that he or she can judge all things. The reason for this is that the human being who has been filled with the Spirit of God can distinguish the meaning (nous) of the Lord in all things so that the Spirit can reveal the deepest secrets of God to them. In this, they stand in contrast to those who do not have the Spirit and who cannot understand the wisdom of God. Should believers live from the vantage point of this portion of Scripture, they have to be convinced of the fact that they can contribute to the solution of the problem of corruption.

In 1 Corinthians 12:1, Paul says that he wishes to inform the congregation about the pneumaticon. Pneumaticon is, in this verse, sometimes translated as spiritual gifts, but it can also be translated (as in 1 Cor 2:15 and 3:1, 14:37) with 'those who have the Spirit' (Dunn 2006:554). The latter translation is probably the right choice on the basis of the fact that, in the following two verses, there is a contrast between the lives of members before and after they received the Spirit. Then he goes on to instruct the congregation about how somebody who has the Spirit has to live as part of the congregation and also how a Spirit-imbued congregation should live. Verse 4-6 offers the structure according to which the chapter has been constructed (Vos 1993:260; Collins \& Harrington 1999:449; Breed 2012:5). Verse 4 indicates that there are many gifts but one Spirit (Pneuma) that confers it. Verse 5 indicates that there are many ministries (diakonia) but only one Lord (Kurios). Verse 6 indicates that there is a variety of powerful workings (energema) but only one God (Theos). Verses 7-11 deal with the gifts of the Spirit as a further extension of the information of verse 4 . This section begins with the information that the Spirit gives gifts to everybody (variety) to the advantage of all (unity) and closes with the information that one and the same Spirit works in each (ekastos) with unique (idios) gifts.

Verse 12 represents a clear transition to the topic dealt with in verse 5 , viz. the practical living of the gifts conferred by the Spirit. It becomes clear from this that verses 12-27 deal with the unity and the diversity of the different parts of the body. The emphasis is on the service rendered by the different limbs (Berding 2006:103). Verse 12 links up with verse 11 and provides the reason (gar) why the Spirit confers a unique gift on each and every one. The reason is to be found in the fact that Christ is like a body: 'The body is a unit, though it is made up of many parts; and though all its parts are many, they form one body. So it is with Christ.' This is a profound 
insight - in this verse, Paul describes Christ's body, the church, but in verse 12 , he says that it is Christ himself that he describes. The body therefore acts here as if it is Christ himself that acts (Bruce 2000:281). The unity and the diversity of the body's diakonia describe the diakonia of Christ.

The emphasis in these verses falls on the different parts of the body and the unique service rendered by each. Although each one has a different function, each one is essential and needs the others. This deals with the service (diakonia) of the body and is about the Lord (Christ) who binds the body as a unity. This section closes with the purpose of the diakonia, viz. that all the members have to care for each other equally and that the members should live for each other intensely and suffer with each other whilst also rejoicing with each other (Berding 2006:105; Hastings 2007:33). Even the gift of the member who would seem to be the least may not be looked down upon, and these seemingly lesser members must be treated and cared for with great respect (Dunn 2006:551-552).

The final verse (v. 27) in this section links up clearly with verse 12 . There is a variety of members, but together, they form one body, as does Christ (v. 12). In this way, the Lord's body (congregation, church) is a diversity moulded into a unity by the Trinitarian God (v. 27; cf. also vv. 4-6).

The diakonia of Christ that the believers get to share through the application of their gifts is service work directed at the salvation of the world (Mk 10:45). After all, Jesus came to seek what was lost (Lk 19:10) and to heal the sick (Lk 5:30, 31). He would also ultimately judge mankind on the basis of their diakonia (Mt 25:44) to him, and this has to find expression in the caring for those in need (Mt 25:41). The third transition is found in verse 28. According to the structure that Paul announced in verses $4-6$, the energema worked by God is described. The meaning of energema can be deduced from the way in which the word group (energeia, energeo, energes), of which this word is a part, is used. This word group points to the powerful and effective working of somebody or something (Dunn 2006:554).

In verse 28 it is said that God (Theos) had given a particular energeia to the congregation through which the gifts could go over to diakonia to the advantage of all. This energeia, God gave in a particular order: first to the Apostles - God works through the testimony of the apostles who had to establish the church. In the founding years of the church, the prophets had to explain and interpret the witnesses' words and apply them. They were followed by the ministers who had to equip the believers for purposes of doing their service-directed work. Here God also used other gifts through which he works powerfully (cf. Berding 2006:306).

From the above the following can be deduced:

- The person who received the Spirit of God also receives gifts that enable him or her to obtain part of Christ's diakonia.

- When Spirit-filled people apply their gifts, God works powerfully and effectively through their service work within and outside of the congregation.
- Both the unity and the diversity in the body of Christ must be fully acknowledged and extended as this is unity and diversity within Christ himself.

- Each member of the body has a contribution and a caring action that is important within God's plan.

- When the members, according to the place accorded to them by God and with the gifts that the Spirit works in them, fulfil Christ's diakonia, change occurs according to God's plan.

\section{Action-oriented research}

It became clear to the researchers that action-oriented research (AOR) implements the principles expounded in 1 Corinthians 12 for the diakonia of the congregation. AOR will now be described, from the perspective of the research for this article, as a further step to enable us to arrive at a recommendation for a possible solution to the problem of corruption in South Africa.

Researchers have engaged in AOR for at least 70 years (Boog 2003:429-431; Cassel \& Johnson 2006:783). There is a wide diversity of approaches to AOR and also a variety of definitions. Cassel and Johnson (2006) provide the various definitions and also indicate how they complement each other. In Handbook of action research, AOR is described from a variety of angles. L'Etang and Theron (2012) describe a project where AOR was applied in practice. The current article does not seek to go into all aspects of AOR, but it only wants to focus on some applicable facets.

For the purposes of this article, the most relevant facet of AOR is that it operates from the premise that all role players are involved at an equal level in order to find a solution. Worthington, Miller and Talley (2011:211) define AOR as follows:

Action-oriented research is a collaborative, applied research effort that brings together community practitioners and academic researchers to generate data that can inform and benefit the community and eventually contribute to general knowledge. Action-oriented research is designed collaboratively by researcher and community. (p. 211)

This definition, however, does not do justice to the full wealth of AOR, and different researchers describe further aspects of it (cf. Bargal 2008:17). For the purposes of this article, it is enough to note the purpose, method and multidimensionality of this method of research.

\section{The purpose and aim of action-oriented research}

Ongoing research: The ultimate purpose of AOR is the improvement of a specific situation within a given community. This, however, involves the objective of equipping the community with the knowledge and skills to contribute to the on-going efforts to find, apply and adjust some strategies. AOR is on-going research and for that reason to some extent experimental. The first practical implementation of a possible solution is seen only as a further step in the research, and therefore, it implies a learning curve. Feedback about 
the effectiveness of the solution, as well as research into the question for better solutions on the basis of problems experienced constitutes part of the process-driven nature of AOR. As solutions are implemented and the situation changes as a result of such implementation, the changed situation is studied, and the quest continued for higher levels of effectiveness. The on-going research and the implementation of solutions keep on opening new doors or indicating new directions.

Multi-dimensional research: AOR gives recognition to the fact that a single researcher or institution cannot necessarily have all the knowledge and skills to arrive at the best solution. Research about the different facets of a problem and the particular person that might be best equipped to deal with a problem at a specific level constitutes an integral part of AOR. Because AOR takes into consideration the people experiencing the problem as well as their culture or situation, one can never simply accept one solution as being applicable to all situations. This form of research remains a dynamic process in which the contribution of each relevant party should be considered and each contribution has the potential of indicating a new direction.

There is already a significant body of research that can help to address the problems in South Africa, but these research results are not at present interlinked and taken into the practical sphere to be tested and evaluated by the community. Very useful information is therefore doomed to remain on bookshelves unread.

From the above the following can be deduced:

- AOR has the following principles in common with the principles discovered in 1 Corinthians 12:

- It has a variety of gifts that co-operate to reach one goal.

- Even the least important member of the team's contribution has to be taken seriously.

- The realisation of the mutual dependence and the reason for the need for good relationships.

- The contribution of the individual is aimed at the well-being of the whole.

- The purpose of the project is elevated above the interests of the individual whilst the achievement of the purpose of each individual is important, even the one making the smallest contribution.

- AOR is especially suited as supportive resource for the church whereby the Lord's diakonia can be achieved.

- AOR can contribute to solving the corruption problem in South Africa.

\section{Touching Africa}

Touching Africa can serve as an example of a company that already applies many of the principles of 1 Corinthians 12 and AOR in their approach to projects that they take on. The vision of this company is "To "Touch" Africa through a diversity of functions and services', and the way in which they wish to achieve it is formulated as follows: 'We believe that a multi-disciplinary vision driven network-to-network

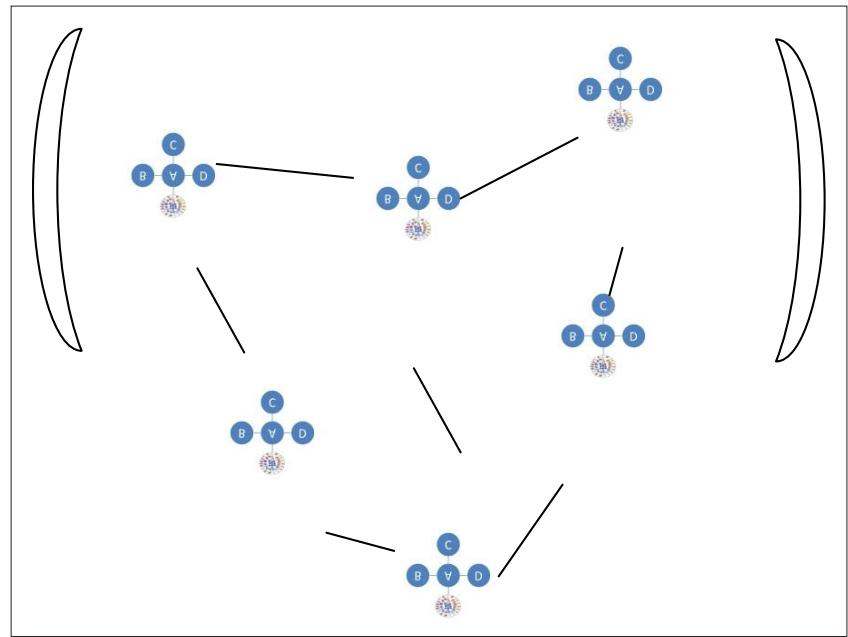

Source: Pretorius, S., 2012, Touching Africa, PowerPoint presentation made at the offices of Touching Africa, Potchefstroom, 28 March 2012

FIGURE 1: Change through a multi-disciplinary combination of vision-driven networks.

framework will change Africa, and Africa the world!' (http:/ / www.touching-africa.com/?q=node/25). They represent this as follows in a schematic format (see Figure 1).

When one looks at their 'operating principles', the similarity with the principles of 1 Corinthians 12 and AOR are very apparent. Only a few principles ${ }^{7}$ will be accentuated below.

\section{Principle 1: Sustainable development is based on a changed mind-set}

The convictions of all role players in a specific project must be brought together and aligned (cf. principle 2 below), and for this to happen, it is essential that attitudes and convictions sometimes have to be changed. You therefore have to 'start within the framework of the people: think like them' and 'develop the mindset of the people'.

AOR works on this same basis, seeing that it also presupposes a multi-disciplinary team, including the end users, who have to be united in their convictions about the purpose, direction and method needed for a particular project. 1 Corinthians 12:1 makes it clear that the sine qua non for participation in the gifts and building of the body is faith in Jesus Christ. The main task of the church is to effect change in people's convictions about a particular issue (Vorster 2012). An example where this principle is put into practice by Touching Africa is the STOP project ${ }^{8}$. They write on their web page (Touching Africa n.d.):

Who is STOP and what do we do? STOP, which stands for 'Stop Trafficking of People', is a non-profit alliance of like-hearted representatives from organizations that are actively involved in the fight against trafficking.

The key objectives of STOP are to:

- raise awareness of human trafficking in South Africa, particularly amongst those most at risk;

7.All information about the principles of Touching Africa was obtained from a PowerPoint presentation by Dr Stefan Pretorius (28 March 2012).

8.All the examples of projects can be seen on the web page: http://www.touching africa.com/?q=node/25 and in the touching Africa gazette at http://www.touching africa.com/?q=node/20 
- mobilize the public, starting with the church, to speak up for those who cannot speak for themselves;

- mobilize the public to assist victims; and

- mobilize the public to address the root causes of human trafficking.

\section{Principle 2: Sustainable development flows from unity in vision}

This principle accords with the principle of the body model expounded in 1 Corinthians 12, viz. that the gifts that everyone in the congregation receives should be applied for the good of all. AOR involves various role players and draws them in to work towards the achievement of one shared purpose. An example where this principle is put into practice is the Thalèta Terri Care Centre of Touching Africa were women suffering from unwanted pregnancies, abortions and abuse are helped to shape their future. They write on their web page: 'We are part of a bigger support network, as such we are affiliated to Africa Cares for Life, Focus on the Family and Heartbeat International' (Touching Africa n.d.).

\section{Principle 3: Sustainable development flows from integration of all role-players}

In 1 Corinthians 12, strong emphasis is placed on the need for each part of the body to be there. The similarity with AOR is also very clear in the sense that each role player is drawn in to make a contribution. Touching Africa works in close relationship with the engineering company Ages ${ }^{9}$. Wherever Ages starts a new project like a new waterworks plant, they first go in and talk to the local people, show them their plans for the project and ask their advice. They also equip them with knowledge, in this case about sanitation and growing their own vegetables. Another example is the Foundation for Farming project where Touching Africa is the facilitator 'using the technologies of Foundations for Farming whilst using AGES as consultants'. The Barolong clan plays a major role in this project by providing land. Several role players contribute to this project, some in the field of research, but the purpose is the self-sustainment of the community.

\section{Principle 4: Sustainable development results from a focus on the end-user}

1 Corinthians 12 focuses the attention on the whole that cares for the individual. If one member suffers, all the others suffer with him or her - and equally they rejoice together. The focus is therefore on the outcome of the caring for others in suffering and in joy, that is, the end user of the caring. AOR involves the end user in the research and obtains feedback about the effectiveness of a solution. The end user therefore plays a cardinal role in the research. The Isandla Usizo project is an example where this principle is put into practice (Touching Africa n.d.):

The aim of the Isandla Usizo Programme is to coach children in fundamental life principles to help them build productive lives and to shape the way in which they see themselves and their realities.

9.The whole supporting network of Touching Africa can be seen on the web page http://www.touching-africa.com/?q=node/18. Part of this network is consulting companies who can do the research for a project on an on-going basis.
The programs developed as the feedback and response of the children showed new possibilities or sent them back to the drawing board.

\section{Principle 5: Operate from your identity as point of departure}

It has become clear from the discussion of 1 Corinthians 12 that identity plays a determining role in the body of Christ. The identity of those who have the Spirit of God becomes clear from the confession of Christ as Lord. The gifts, diakonia and the forces within the congregation find their identity and unity in the Trinitarian God.

The congregation is the body of Christ and like Christ reveals unity in diversity. The church should not merely ask: 'What should we do?' The church should in the first place ask: 'Who are we?' When their deeds flow from what they are, their identity in Christ as Spirit-filled and gifted people, then they can serve others sustainably. Touching Africa is a company that operates from the basis of their identity as captured in a vision that unites. They are therefore not only working towards complying with the government's BEE requirements but also fulfilling their principles and vision in line with the identity that they have purposefully constructed. Many successful projects have flowed from their actions as embedded in the above principles ${ }^{10}$.

From the above the following can be deduced:

- Touching Africa is a company that is managed in line with various principles that also occur in 1 Corinthians 12 and in AOR.

- The probable success of this modus operandi has been proven in practice in various projects driven by Touching Africa where some of the principles of 1 Corinthians 12 and AOR were followed.

- The principles proposed in both 1 Corinthians 12 and AOR, some of which have also been successfully implemented by Touching Africa, can serve as a basis for a model to find a solution for the effects of corruption in South Africa.

\section{Possible guidelines for the quest for solutions against corruption}

As indicated in this research, the assumption of the researchers is that the Bible determines not only what the church must do but also what the church must be in this world. Therefore, from the foregoing research, the following proposal is made to serve as guidelines for the quest for solutions when it comes to the fight against corruption in South Africa:

- The church has to act in society as an awareness-raiser and opinion-former (Vorster 2012).

- A well-co-ordinated project is needed to address the problem of corruption and other problems in South Africa. This project will have to be based on sound research, and therefore, universities will have to be involved. Established researchers as well as masters' and doctoral students

10.Projects that they are working on at present can be seen on their website (www. touching-africa.com). 
from different disciplines will have to do research on an organised basis about identified problem areas.

- The initial research will have to identify the areas where problems exist that can give rise to corruption and other problems. Following that, experts who are willing to undertake $\mathrm{AOR}$ in their fields of specialisation must be identified and activated.

- In this research, the community will be closely involved both companies and individuals, leaders and people who are at the lowest levels of the labour market or are even unemployed.

- Some of the fields in which research should be done include education, the economy, environmental conservation, the legal system, correctional services, agriculture and the upliftment of people who suffered as a result of corruption.

- Companies should be approached who buy into the vision of designing a holistic strategy. These companies can make available their expertise and financial help. Companies that contribute can test and give feedback on the models constructed on the basis of AOR.

- A scientifically-founded holistic plan has to be constructed in this way in order to create a sustainable lebensraum for the people of South Africa, and later for Africa and even for the world.

- An organisation that enjoys the trust of society should be the co-ordinator of this action and serve to run the finances.

- The churches in South Africa should establish a joint forum that can serve as the initial initiator and co-ordinator of this project. Following this, the project should be managed by organisations that specialise in different spheres.

\section{Conclusion}

From the first part of this article the devastating impact of corruption on people emerged clearly. It also became clear, however, that all the parties involved in the rendition of aid were or are to some extent helpless and unable to do everything that they knew to be necessary in order to render really effective help. The co-operation that developed between various groupings and institutions began to point to a possible solution.

In the second part of the article, it became clear that the Trinitarian God mercifully grants the church insight, wisdom and gifts to enable members of the church to continue Christ's service work (diakonia) here on earth so that help can be rendered effectively.

It also became clear that God is a God of unity and diversity and that the diakonia of the church can only reach its full potential when both the unity and the diversity are respected. The diakonia to which the church has been called is the diakonia of Christ who did not come to be served but to serve and to give his life as a price to overcome the forces of Satan and to cleanse the pain brought about by sin. He came to heal the sick and the wounded but also to address injustice and corruption. When the church continues its diakonia, they have to serve him as the healer and the judge of people in this world. The church has a leadership role to fulfil in the world, as Jesus also did. For that reason, where injustice and corruption are found, with concomitant pain, poverty and suffering, the church cannot sit back and say that it is not her problem. It is also important, however, that the church should not act outside her mandate (Vorster 2012).

In the third part of this article, it became clear that AOR is a useful resource that fits in with the principles according to which the church has to operate and that it contributes to the discovery of the roots of problems that manifest, amongst others, in corruption - and to address such problems.

In the fourth part, proof was found that the principles of 1 Corinthians 12 and AOR can be successfully applied in practice and that, in effect, Touching Africa has been successful in doing this. Vorster (2012) identifies three levels where the church can become involved in fighting corruption: 'They can raise awareness of the problem, address the underlying attitude of self-interest and call for social justice.' One can add a fourth level here, viz. the leadership role of the church in the initiation and facilitation of co-operation in addressing problems.

Finally, in the last part of the article, a possible proposal was made which can serve as guidelines for churches in the quest for solutions when it comes to the fight against corruption in South Africa. The Bible determines not only what the church must do but also what the church must be in this world.

\section{Acknowledgements Competing interests}

The authors declare that they have no financial or personal relationship(s) which may have inappropriately influenced them in writing this article.

\section{Authors' contributions}

A.L.d.P. (North-West University) was responsible for the first part of the article, that is, empirical research (field trips and evaluation) regarding the alleged corruption of the Aurora Mine group. G.B. (North-West University) was responsible for the second part of the article, that is, the normative and pragmatic aspects.

\section{References}

Bargal, D., 2008, 'Action research: A paradigm for achieving social change', Small Group Research 39(1), 17-27. http://dx.doi.org/10.1177/1046496407313407

Berding, K., 2006, What are spiritual gifts?: Rethinking the conventional view, Kregel Publications, Grand Rapids.

Boog, B.W.M., 2003, 'The emancipatory character of action research, its history and the present state of the art', Journal of Community \& Applied Social Psychology 13(1), 426-438. http://dx.doi.org/10.1002/casp.748

Breed, G., 2012, 'Nuut gedink oor die wese en inhoud van die dienswerk van die diaken', HTS Teologiese Studies/Theological Studies 68(1), 1-17. http://dx.doi.org/10.4102/ hts.v68i1.1059

Bruce, F.F., 2000, Paul, apostle of the heart set free, Eerdmans, Grand Rapids.

Cassell, C. \& Johnson, P., 2006, 'Action research: Explaining the diversity', Human Relations 54(6), 783-814. http://dx.doi.org/10.1177/0018726706067080

Collins, R.F. \& Harrington, D.J., 1999, First Corinthians, Liturgical Press, Collegeville.

Dunn, J.D.G., 2006, The theology of Paul the Apostle, Eerdmans, Grand Rapids. 
Hall, M.E.L., Langer, R. \& McMartin, J., 2010, 'The role of suffering in human flourishing: Contributions from positive psychology, theology, and philosophy', Journal of Contributions from positive psychology and Theology 38(2), 111-121.
Psychol

Hastings, T., 2007, Practical Theology and the one body of Christ: Toward a missionalecumenical model, Eerdmans, Grand Rapids.

L'Etang, S. \& Theron, L., 2012, 'A critical reflection on the participatory action process involved in the development of a cognitive-behavioural-based counselling intervention programme for youth living with HIV/AIDS in a rural South African town', Action Research 10(1), 5-21. http://dx.doi.org/10.1177/1476750311414740

Osmer, R., 2008, Practical theology: An introduction, Eerdmans, Grand Rapids.

Pauw, J., 2012, 'Aurora "was virtually run as a Ponzi scheme"', City Press, 25 March, p. 3.

Pretorius, S., 2012, Touching Africa, PowerPoint presentation made at the offices of Touching Africa, Potchefstroom, 28 March 2012.
Retief, Y., 2010, Genesing vir trauma in die Suid Afrikaanse konteks, Struik Christelike Boeke, Kaapstad.

Strydom, H., 1999, 'Maatskaplikewerk-navorsing', ongepubliseerde studie gids, Potchefstroom.

Touching Africa, n.d., Projects, viewed, n.d., from http://www.touching-africa.com/ ?q=node $/ 25$

Vorster, J.M., 2012, 'Managing corruption in South Africa: The ethical responsibility of churches', Scriptura 109, 133-147.

Vos, J.S., 1993, 'Das Rätsel von 1 Kor 12:1-3 [The riddle of 1 Cor. 12:1-3]', Novum Testamentum 35(3), 251-269. http://dx.doi.org/10.1163/156853693X00167

Worthington, E.L., Miller, E.J. \& Talley, J.C., 2011, 'Action-oriented research: A primer and examples', Journal of Psychology and Theology 39(3), 211-221.

Worrall, D., 2011, 'Korrupsie: Deel van SA se werklikheid?', Rapport, 16 Oktober, bl. 3. 